\section{Do Inventories Moderate Fluctuations in Output?}

\section{Donald S. Allen}

in he movement of aggregate inventory investment appears to play a major role in business-cycle dynamics. Economists continue to explore the idea that large unexpected slowdowns in demand may cause an excessive amount of inventory to build up, causing a slowdown in output as firms cut back on production until inventories return to normal. A previous article in this publication (Allen, 1995) discusses the potential impact of changing inventory management methods on the frequency and depth of recessions. Although the findings are inconclusive, the potential effect of inventory movement on the business cycle warrants continued research. In addition, some authors argue that monetary policy has its primary impact through an effect on inventory investment. If this is the case, then it is important for monetary policymakers to understand how the decisions on inventory investment- that is, periodic changes in inventory-are made.

In spite of the large amount of research on inventories, many questions remain. This article tries to answer two of several open questions identified by Lovell (1994): First, do firms use inventories to schedule production efficiently? Specifically, do firms use inventories to smooth production in the face of uncertain demand? Second, are problems of aggregation important? More directly, do problems of aggregation account for economists' failure to confirm smoothing by analyzing aggregate inventory data?
Inventories allow firms to supply unexpected demand without having to adjust output immediately. When firms face increasing marginal costs of production, using inventory to smooth production is efficient, as long as the savings from not adjusting production exceed the cost of holding inventory. Inventory acts as a buffer stock, absorbing increases or decreases in demand while production remains relatively steady. If firms are smoothing production, then we would expect sales to vary more than production: The variance of production should be less than the variance of sales. If inventories are used as a buffer stock, then high-frequency changes in inventory should be in the opposite direction to sales. Empirical research using aggregate data does not confirm this intuition. Inventory researchers (Blinder, 1986, for example) have found that production varies more than sales and that the covariance of changes in inventory and sales is actually positive. These stylized facts imply that either the production-smoothing, buffer stock model is incorrect, ${ }^{1}$ or there are other factors that prevent empirical confirmation of the smoothing effect.

Most of the research that finds contradictions of production smoothing uses seasonally adjusted aggregate data of inventory and sales. It is possible that firms actually do use inventory to smooth production and that the empirical research has failed to detect the signs of this activity because the data are too highly aggregated over many firms. This article uses firmlevel data from COM PUSTAT to test whether the stylized facts hold at the firm level and at the aggregate level over firms in the same 2-digit SIC code. The data are for publicly traded firms in a variety of SIC codes. The results are still negative for the production-smoothing model, however. Statistical tests in which the ratio of the variance of the value of production to the variance of the value of sales is used as a measure of production smoothing fail to

\footnotetext{
${ }^{1}$ An alternative inventory model called $(S, S)$, suggests that firms with fixed costs of adjusting inventory will establish a maximum level of inventory $(S)$, and a minimum level ( $s$, and adjust only when inventory falls below the minimum [ $\mathrm{See}$ Allen (1995) for a brief explanation of production smoothing and $(S, S)]$. The $(S, S)$ model is less likely to have production varying less than sales. The purpose of this article is to test the production smoothing model only.
} 
confirm smoothing in the majority of the SIC codes, both at the firm level and the aggregate level.

An alternative reason for the failure of the production-smoothing test is that firms also consider other factors in managing inventory. If there are severe economic penalties for running out of stock, then firms may plan to maintain some average level of inventory relative to sales over a planning horizon (see West, 1986). If increasing demand or large shocks to sales reduce inventory below this level, then a portion of production will be used to increase inventory. If this "planned" addition to inventory is large enough, the variance ratio test for smoothing will fail. A test of a model in which firms smooth around a target inventory-to-sales (I/S) ratio appears to support the buffer-stock nature of inventories.

The paper is organized as follows: The first section gives a description of the data. The next section discusses the results of tests of the production-smoothing hypothesis. The third section proposes a simple model of partial adjustment to a target inventory level. It shows the results of tests of the buffer-stock hypothesis using the correlation of changes in inventory to changes in sales at the firm level and SIC code level. N ext, some specific firm data are provided for illustrative purposes, and a summary and conclusions follow.

\section{DESCRIPTION OF DATA}

The COMPUSTAT data are individual firm data on inventory and sales for publicly traded firms for the period from the first quarter of 1981 to the fourth quarter of 1991, as reported in balance sheets and income information. The original dataset contains financial information from 6,984 firms across several SIC codes. Data for all 44 quarters were not available for all firms. An average of about 31 quarters of sales data per company was available. There were 42 companies with duplicate information due to accounting changes. Some firms reported data only annually or semi-annually, while others had missing quarters. Duplicate companies, companies with nonconsecutive quarters, and SIC codes for which the notion of inventory did not correspond to the product offered for sale-for example, services - were eliminated. The last three quarters of 1991 were dropped because of insufficient data. The final dataset comprises information from 2452 companies with an average of 29 quarters of data per company over the sample period.

Table $A$ in the appendix summarizes descriptive statistics by 2-digit SIC codes. $M$ ining industries are grouped in SIC codes 10 through 14; construction establishments are in SIC codes 15, 16, and 17; SIC codes 20 through 39 are manufacturing industries; SIC codes 50 and 51 are wholesale establishments; and SIC codes 52 through 59 are retail establishments.

Average quarterly sales in each SIC code range from $\$ 588$ million in SIC code 10 (metal mining) to $\$ 106.1$ billion in SIC code 29 (petroleum and coal products). The ratios of mean quarterly inventory to mean quarterly sales range from 0.17 to 1.38 . This range compares to a peak monthly inventory-to-sales ratio for total business of 1.7 during the 1981-82 recession and 1.36 in A pril 1997. A 1.36 ratio of inventory to monthly sales is approximately equival ent to 0.46 as a ratio of quarterly sales.

Aggregation of firms within SIC codes is performed separately for changes and levels. That is, sales and inventory are summed over firms within the same 2-digit SIC code, but changes in sales and/or inventory for the SIC code are computed by adding the changes in sales and/or inventory for each company in the sample during the quarter instead of taking the difference of the aggregate sales and/or inventory. Firms are included in the sample after the second period for which data are available, so that both changes and levels are included. This procedure was adopted because firms are added and dropped throughout the sample period. The value of production is estimated to be the sum of the value of sales and the value of the change in inventory for each quarter. 


\section{RESULTS}

\section{Variance Ratio}

The typical measure of smoothing uses the ratio of the variance of production to the variance of sales. Variance ratios greater than 1.0 suggest that production varies more than sales, contradicting the expected results of smoothing. Similarly, ratios less than 1.0 confirm smoothing. Lovell (1993) questions the use of this ratio as a measure of smoothing for reasons related to aggregation and sectoral interaction between companies- that is, manufacturing firms, wholesale firms, and retailers all hold inventory and can be suppliers or customers of each other. Inventory movements of each sector can be offsetting or synchronized. Summing inventory over all firms, both downstream and within the same sector, can distort the variance ratios. The objective of this article is to test whether aggregating up to the 2-digit SIC code level can induce changes in the variance ratio measure. It does not necessarily endorse the validity of the measure.

The results in Table 1 show that virtually all ratios computed were greater than 1.0 for both the aggregate and individual firms in each SIC code. Only three SIC codes (14, 29, and 59) had aggregate variance ratios less than 1.0 , and only three $\mathrm{SIC}$ codes (31, 53, and 59) had average firm variance ratios less than 1.0. Aggregating over firms in the same 2-digit SIC codes and comparing to the average firm-level variance ratios with the variance ratio of the aggregate suggests that aggregation does have a negative effect on the variance ratio when smoothing is confirmed for the average firms. For SIC code 53, the average variance of all firms is 0.85 , but the variance ratio of the aggregate SIC code 53 is 1.01 . In general, however, the variance ratio of the aggregate is less than the average variance ratio of the individual firms.

The value of production is estimated as the sum of sales and the change in inventory for that period, as shown in Equation 1 below:

$$
\begin{aligned}
& P_{t}=X_{t}+N_{t}-N_{t-1} \\
& \quad \text { or } \\
& P_{t}=X_{t}+\Delta N_{t},
\end{aligned}
$$

where $P$ is production, $X$ is sales, and $N$ is inventory. The variance of the value of production is then equal to the sum of the variance of sales, the variance of the change in inventory, and twice the covariance of sales and the change in inventory. Therefore, for the variance of production to be less than the variance of sales, the covariance term must be negative and more than half the value of the variance of the change in inventory.

The last column in Table 1 shows the sign of the covariance of sales and changes in inventory for the aggregate of the 2-digit $\mathrm{SIC}$ codes. There are 10 industries in which the covariance of sales and the change in inventory are negative, but in seven of these the negative covariance is less than half the variance of the change in inventories, leading to a variance ratio greater than 1.0.

Estimating production by adding sales revenue to changes in inventory each quarter instead of counting actual physical stock generally has had less success in confirming production smoothing. One reason could be the existence of mark-ups over production costs. Since firms have several dimensions along which to adjust, they can adjust on the price or quantity margin; production of physical units may be only loosely connected to sales revenue. In other words, a change in sales revenue can reflect a change in price or a change in quantity sold, or both. ${ }^{2}$

Another explanation of the variance ratio test's failure to confirm smoothing is that firms may attempt to maintain average inventory at a fixed proportion of average sales, so that if sales are trending up, then inventory will also trend up. ${ }^{3}$ West (1986) and others recognized that when firms maintain inventory for stockout avoidance, production smoothing will not be

\footnotetext{
${ }^{2}$ The relative success of some researchers who use physicalproduct data in confiming production smoothing (Ghali, 1987; Fair, 1989; and Krane and Braun, 1991) suggests that seasonal adjustments and price flexibility (e.g., liquidation sales) may distort the relationships between value-based variables and quantity. This distortion may account for the failure to confirm smoothing by using value-based data. Unfortunately, this hypothesis is not tested here, but work by Miron and Zeldes (1988) found that seasonal adjustment did not appear to affect the empirical rejection of production smoothing.

${ }^{3}$ Detrending aggregate data is one method used to remove this trend effect Typical methods of detrending can introduce further distortion into the data.
} 


\section{Table 1}

\section{Variance Ratio}

Ratio of Variance of Production Sales and Change to Variance of Sales in Inventory

\begin{tabular}{|c|c|c|c|c|c|c|}
\hline SIC Code & Industry & \# of Cos. & Average & $\begin{array}{l}\text { Weighted } \\
\text { Average }\end{array}$ & Aggregate & Aggregate \\
\hline 10 & Metal mining & 32 & 1.34 & 1.14 & 1.04 & + \\
\hline 12 & Coal mining & 4 & 1.02 & 1.05 & 1.01 & - \\
\hline 13 & Oil and gas extraction & 99 & 1.42 & 1.12 & 1.01 & + \\
\hline 14 & Nonmetallic minerals, except fuels & 8 & 1.06 & 0.99 & 0.99 & - \\
\hline 15 & General building contractors & 36 & 360.02 & 2.16 & 1.07 & - \\
\hline 16 & Heavy construction, except bldg. & 12 & 1.03 & 1.08 & 1.00 & + \\
\hline 17 & Special trade contractors & 17 & 1.08 & 1.07 & 1.06 & + \\
\hline 20 & Food and kindred products & 100 & 1.37 & 1.13 & 1.03 & + \\
\hline 21 & Tobacco products & 7 & 1.17 & 1.21 & 1.02 & - \\
\hline 22 & Textile mill products & 40 & 1.10 & 1.24 & 1.02 & - \\
\hline 23 & Apparel and other textile products & 45 & 1.14 & 1.02 & 1.03 & + \\
\hline 24 & Lumber and wood products & 27 & 1.04 & 1.08 & 1.01 & + \\
\hline 25 & Furniture and fixtures & 30 & 1.07 & 1.17 & 1.03 & + \\
\hline 26 & Paper and allied products & 47 & 48.65 & 1.07 & 1.02 & + \\
\hline 27 & Printing and publishing & 66 & 1.08 & 0.99 & 1.00 & + \\
\hline 28 & Chemicals and allied products & 185 & 1.46 & 1.06 & 1.02 & + \\
\hline 29 & Petroleum and coal products & 37 & 1.07 & 1.05 & 1.00 & - \\
\hline 30 & Rubber and misc. plastics products & 65 & 1.13 & 1.04 & 1.00 & + \\
\hline 31 & Leather and leather products & 18 & 0.89 & 1.04 & 1.02 & + \\
\hline 32 & Stone, day, and glass products & 25 & 1.78 & 1.03 & 1.01 & + \\
\hline 33 & Primary metal industries & 80 & 1.30 & 1.21 & 1.02 & + \\
\hline 34 & Fabricated metal products & 83 & 1.23 & 1.11 & 1.03 & + \\
\hline 35 & Industrial mach. and equip. & 289 & 5.72 & 1.04 & 1.02 & + \\
\hline 36 & Electronic and other elect. equip. & 263 & 1.51 & 1.05 & 1.02 & + \\
\hline 37 & Transportation equipment & 100 & 1.08 & 1.03 & 1.01 & + \\
\hline 38 & Instruments and related prods. & 226 & 1.30 & 1.06 & 1.01 & + \\
\hline 39 & Misc. manuf. industries & 51 & 1.07 & 1.00 & 1.01 & - \\
\hline 50 & Wholesale durable goods & 126 & 1.49 & 1.17 & 1.03 & + \\
\hline 51 & Wholesale nondurable goods & 67 & 1.23 & 1.01 & 1.01 & + \\
\hline 52 & $\begin{array}{l}\text { Retail building materials } \\
\text { and garden supplies }\end{array}$ & 14 & 1.14 & 1.06 & 1.06 & + \\
\hline 53 & Retail genl. merchandise stores & 46 & 0.85 & 0.87 & 1.01 & - \\
\hline 54 & Retail food stores & 40 & 1.04 & 1.05 & 1.01 & + \\
\hline 55 & Auto dlrs. and service stations & 5 & 3.31 & 1.16 & 1.08 & + \\
\hline 56 & Retail apparel and acces. stores & 31 & 1.00 & 0.96 & 1.02 & - \\
\hline 57 & $\begin{array}{l}\text { Retail furniture and } \\
\text { home furnishings stores }\end{array}$ & 24 & 1.08 & 1.02 & 1.06 & + \\
\hline 58 & Retail eating and drinking places & 54 & 1.03 & 1.01 & 1.00 & + \\
\hline 59 & Misc, retail establishments & 53 & 0.93 & 0.91 & 0.97 & - \\
\hline
\end{tabular}


confirmed in the data. In this case a portion of inventory change ("planned inventory changes") will move together with sales, while a portion of inventory change ("unplanned inventory changes") will move in the opposite direction to sales as a buffer stock. Since production is computed as the sum of sales and the contribution to (change in ) inventory each period, if the planned inventory changes overwhelm the unplanned changes in inventory, then production will have a higher variance than sales. A simple model of this behavior implies that the change in inventory should nonetheless be negatively correlated with the change in sales. For almost all SIC codes, changes in inventory and changes in sales are indeed negatively correlated. This result suggests that inventories do act as buffer stock for unexpected changes in sales. The next section proposes the model and tests the implications of this hypothesis.

\section{A SMOOTHING MODEL WITH A TARGET I/ S RATIO}

It is possible that firms smooth production over some horizon but also adjust production to maintain a mean desired inventory level at a fixed proportion of sales. A stockout avoidance motivation would favor an optimal inventoryto-sales ratio. Although, theoretically, the ratio of inventory to sal es which minimizes the risk of running out of stock should fall as average sales increase, the aggregate data appear to show that firms keep the ratio relatively constant. If we assume that sales are serially correlated and that industries adjust partially to the desired inventory-to-sales ratio, then a portion of production will go toward inventory investment. We can consider this to be planned inventory investment. The length of the production planning horizon will determine how often production will be adjusted. Ideally, firms will smooth over a horizon where average sales can be predicted with reasonable accuracy. For simplicity, we assume that firms base their production plans for the next period on last period's sale and the difference between actual and planned inventory. The following equations would describe this process:

$$
\begin{aligned}
X_{t} & =C+\rho X_{t-1}+\varepsilon_{t}, \text { where } \\
\rho & >0 \\
N_{t}^{*} & =\theta X_{t}
\end{aligned}
$$

$$
\begin{aligned}
P_{t} & =X_{t-1}+\gamma\left(N_{t}^{*}-N_{t-1}\right), \text { where } \\
0 & \leq \gamma \leq 1 ; \text { and }
\end{aligned}
$$

$$
\begin{aligned}
\Delta N_{t} & =P_{t}-X_{t} \\
& =\gamma\left(N_{t}^{*}-N_{t-1}\right)-\Delta X_{t},
\end{aligned}
$$

where $X_{t}$ is sales in period $t, C$ is a constant, $\mathrm{N}_{\mathrm{t}}^{*}$ is the desired inventory level and $\mathrm{N}_{\mathrm{t}}$ is the actual inventory level in period $t, \mathrm{P}_{\mathrm{t}}$ is production in period $t$, and $\varepsilon_{\mathrm{t}}$ is a random shock to sales in period t. The coefficient $\theta$ can be assumed to be constant and estimated to be the average inventory to sales ratio. The term $\gamma\left(\mathrm{N}_{\mathrm{t}}^{*}-\mathrm{N}_{\mathrm{t}-1}\right)$ in Equation 5 can be thought of as the "planned" component of inventory investment, where $\gamma$ represents the speed of partial adjustment to desired inventory level, and the term $\Delta \mathrm{X}_{\mathrm{t}}$ can be thought of as the buffer stock movement or "unplanned" inventory investment. The "planned" inventory investment component will be positively correlated with sales if the firm's target inventory is represented by Equation 3, while the un planned term will be negatively correlated with changes in sales as the buffer stock notion implies. ${ }^{4}$

The next section shows the results of testing whether changes in sales and changes in inventory are negatively correlated.

\section{CORRELATION COEFFICIENTS}

For each SIC code and individual firm, I computed the correlation coefficients between the change in sales and the

\footnotetext{
${ }^{4}$ Generally, the correlation between the left-hand variable and the right-hand variables is indeterminate without prior knowledge of the coefficients However, because $\gamma$ and $\theta$ are both less than 1.0 and planned inventory change will be in the same direction as the change in sales, the change in sales should dominate the planned inventory change. In this case, the correlation between the change in sales and change in inventory should be negative.
} 
change in inventory for each period. To get a measure of the relative co-movement of changes in inventory and changes in sales for firms within the SIC code, I computed a simple average of the correlation coefficients. If there is no weighting of individual firms by size, then even if a particular firm comprises most of the aggregate data, the co-movement of that firm's change in inventory and change in sales will not proportionately influence the average correlation coefficient of individual firms. For this reason, I also computed a weighted average of the individual firm correlation coefficients, based on relative contribution to the aggregate.

Table 2 shows the results. About two-thirds of the SIC codes show a negative correlation of the change in aggregate sales to change in aggregate inventory. Likewise, the weighted and unweighted average correlation coefficients of the individual firms are negative for most SIC codes. Of the 13 SIC codes with positive correlations between changes in sales and changes in inventory, five SIC codes show negative average (unweighted) correltion coefficients at the firm level. A few SIC codes show negative correlation coefficients at the aggregate level but positive average correlation coefficients at the firm level. This could be because smaller firms with positive correlations are influencing the data.

The results are consistent with the simple model of partial adjustment. Correlation coefficients remain positive for wholesale and are negative for aggregate manufacturing and retail. This result implies that both firm-level data and aggregated data support the buffer-stock hypothesis.

\section{ESTIMATES OF MODEL COEFFICIENTS}

The anticipated negative correlation coefficients were verified in the previous section. This section estimates the model from the data. Equation 5 of the partial adjustment model can be rear- ranged algebraically in the following equations:

$$
\begin{aligned}
\Delta N_{t} & =C(\gamma \theta-1)+[1+\rho(\gamma \theta-1)] X_{t-1} \\
& -\gamma N_{t-1}+(\gamma \theta-1) \varepsilon_{t}, \text { and }
\end{aligned}
$$

$$
X_{t}=C+\rho X_{t-1}+\varepsilon_{t}
$$

The coefficients of Equations 6 and 2 (repeated above as Equation 7) were estimated by using ordinary least squares. The fraction of sales $(\theta)$ that represents the desired inventory level $\mathrm{N}_{t}^{*}$, is estimated as the average inventory-to-sal es ratio for each SIC code. Table 3 shows the results for each industry, including the constant term. Estimates of the coefficients were the same sign predicted by the equations and statistically significant at either the 95 or 99 percent confidence interval for 25 out of 37 industries for last-period inventory levels and for 21 out of the 37 industries for last-period sales. The coefficient $\gamma$ was negative for two industries, petroleum and coal products and wholesale durable goods, suggesting that these firms may have been reducing inventories during the sample period.

Estimates of $\gamma$ for the 25 industries with significant coefficients ranged from 0.1876 for primary metals to 1.0537 for wholesale nondurable goods and averaged 0.4062 . This means the speed of adjustment toward the desired inventory level ranged from less than one quarter for wholesale nondurables to more than five quarters for primary metals and averaged about two and a half quarters. The inventory-to-sales ratio, or $\theta$, averaged 0.6597 for the 21 industries with significant coefficients on both lagged inventory and lagged sales. Equivalent to about 1.92 months of sales in stock, this figure compares to an average seasonally adjusted figure of 1.54 months of sales for manufacturing and trade.

The results of the correlation coefficient estimates and the regressions are consistent with the notion that some firms are motivated by stockout avoidance, 


\section{Correlation Coefficients}

\begin{tabular}{|c|c|c|c|c|c|}
\hline \multirow[b]{2}{*}{ SIC Code } & \multirow[b]{2}{*}{ Industry } & \multirow[b]{2}{*}{ \# of Cos. } & \multirow{2}{*}{$\begin{array}{l}\text { Aggregate } \\
\text { Correlation } \\
\text { Coefficient }\end{array}$} & \multicolumn{2}{|c|}{$\begin{array}{c}\text { Average } \\
\text { Correlation Coefficient }\end{array}$} \\
\hline & & & & Weighted & Unw eighted \\
\hline 10 & Metal mining & 32 & -0.049 & -0.217 & -0.120 \\
\hline 12 & Coal mining & 4 & -0.479 & -0.065 & -0.086 \\
\hline 13 & Oil and gas extraction & 99 & 0.141 & 0.187 & 0.035 \\
\hline 14 & Nonmetallic minerals, except fuels & 8 & -0.097 & -0.119 & -0.009 \\
\hline 15 & General building contractors & 36 & -0.500 & -0.002 & 0.028 \\
\hline 16 & Heavy construction, except bldg. & 12 & 0.124 & 0.209 & 0.008 \\
\hline 17 & Special trade contractors & 17 & 0.487 & 0.255 & 0.188 \\
\hline 20 & Food and kindred products & 100 & -0.376 & -0.078 & 0.020 \\
\hline 21 & Tobacco products & 7 & -0.287 & -0.059 & -0.171 \\
\hline 22 & Textile mill products & 40 & -0.070 & 0.095 & -0.088 \\
\hline 23 & Apparel and other textile products & 45 & -0.341 & -0.181 & -0.152 \\
\hline 24 & Lumber and wood products & 27 & -0.042 & -0.041 & -0.034 \\
\hline 25 & Furniture and fixtures & 30 & -0.157 & -0.047 & -0.090 \\
\hline 26 & Paper and allied products & 47 & 0.115 & 0.084 & 0.090 \\
\hline 27 & Printing and publishing & 66 & -0.505 & -0.251 & -0.107 \\
\hline 28 & Chemicals and allied products & 185 & 0.098 & 0.042 & -0.071 \\
\hline 29 & Petroleum and coal products & 37 & 0.465 & 0.101 & -0.007 \\
\hline 30 & Rubber and misc. plastics products & 65 & 0.054 & -0.200 & -0.047 \\
\hline 31 & Leather and leather products & 18 & -0.262 & -0.193 & -0.401 \\
\hline 32 & Stone, day, and glass products & 25 & -0.430 & -0.129 & -0.200 \\
\hline 33 & Primary metal industries & 80 & 0.280 & 0.008 & -0.028 \\
\hline 34 & Fabricated metal products & 83 & -0.334 & 0.012 & 0.008 \\
\hline 35 & Industrial mach. and equip. & 289 & -0.649 & -0.219 & -0.051 \\
\hline 36 & Electronic and other elect. equip. & 263 & -0.383 & -0.121 & -0.005 \\
\hline 37 & Transportation equipment & 100 & -0.523 & -0.226 & -0.120 \\
\hline 38 & Instruments and related prods. & 226 & -0.579 & -0.233 & -0.096 \\
\hline 39 & Misc. manuf. industries & 51 & -0.152 & -0.105 & -0.134 \\
\hline 50 & Wholesale durable goods & 126 & 0.344 & 0.154 & 0.118 \\
\hline 51 & Wholesale nondurable goods & 67 & 0.389 & 0.107 & 0.077 \\
\hline 52 & $\begin{array}{l}\text { Retail building materials } \\
\text { and garden supplies }\end{array}$ & 14 & 0.162 & 0.190 & -0.174 \\
\hline 53 & Retail genl. merchandise stores & 46 & -0.719 & -0.441 & -0.441 \\
\hline 54 & Retail food stores & 40 & 0.102 & 0.187 & 0.198 \\
\hline 55 & Auto dlrs. and service stations & 5 & 0.078 & -0.012 & 0.186 \\
\hline 56 & Retail apparel and acces. stores & 31 & -0.639 & -0.455 & -0.287 \\
\hline 57 & $\begin{array}{l}\text { Retail furniture and } \\
\text { home furnishings stores }\end{array}$ & 24 & -0.693 & -0.149 & -0.039 \\
\hline 58 & Retail eating and drinking places & 54 & -0.059 & 0.063 & 0.193 \\
\hline 59 & Misc, retail establishments & 53 & -0.752 & -0.308 & -0.082 \\
\hline
\end{tabular}




\section{Table 3}

\section{OLS estimates of equation coefficients}

\begin{tabular}{|c|c|c|c|c|c|}
\hline SIC Code & Industry & $\gamma$ & $1+\gamma \theta \rho-\rho$ & $\rho$ & $\theta$ \\
\hline 10 & Metal mining & $0.3053^{*}$ & $0.1481^{* *}$ & $0.9928 * *$ & 0.8763 \\
\hline 12 & Coal mining & $0.3585^{* *}$ & $0.1130 *$ & $0.6136^{* *}$ & 0.3150 \\
\hline 13 & Oil and gas extraction & $0.5258^{* *}$ & 0.0562 & $0.8406 * *$ & 0.2768 \\
\hline 14 & Nonmetallic minerals, except fuels & $0.5320 * *$ & -0.0072 & $0.3839 *$ & 0.4190 \\
\hline 15 & General building contractors & $0.2330 * *$ & $0.3174 * *$ & $0.9034^{* *}$ & 1.3834 \\
\hline 16 & Heavy construction, except bldg. & $0.3036 * *$ & 0.0409 & $0.8748 * *$ & 0.3257 \\
\hline 17 & Special trade contractors & 0.0943 & 0.0427 & $0.9785^{* *}$ & 0.2154 \\
\hline 20 & Food and kindred products & $0.5914^{* *}$ & $0.1871^{* *}$ & $0.9651^{* *}$ & 0.4556 \\
\hline 21 & Tobacco products & $0.4102^{* *}$ & $0.2370 * *$ & $0.8864 * *$ & 0.9974 \\
\hline 22 & Textile mill products & $0.3213^{*}$ & 0.2221 & $0.9393 * *$ & 0.7172 \\
\hline 23 & Apparel and other textile products & 0.1509 & 0.1403 & $0.9457^{* *}$ & 0.8645 \\
\hline 24 & Lumber and wood products & $0.4310^{* *}$ & $0.1995^{* *}$ & $0.9470 * *$ & 0.4759 \\
\hline 25 & Furniture and fixtures & $0.4709 * *$ & $0.2219 * *$ & $0.9273^{* *}$ & 0.7401 \\
\hline 26 & Paper and allied products & 0.1078 & 0.0579 & $1.0033^{* *}$ & 0.4836 \\
\hline 27 & Printing and publishing & $0.2980^{*}$ & $0.0690 * *$ & $0.9649 * *$ & 0.2841 \\
\hline 28 & Chemicals and allied products & 0.1260 & 0.0789 & $1.0154^{* *}$ & 0.5739 \\
\hline 29 & Petroleum and coal products & -0.0440 & -0.0205 & $0.8312^{* *}$ & 0.2818 \\
\hline 30 & Rubber and misc. plastics products & $0.3918^{* *}$ & $0.2187^{* *}$ & $0.9828 * *$ & 0.5914 \\
\hline 31 & Leather and leather products & 0.0902 & 0.0610 & $0.7021^{* *}$ & 0.8648 \\
\hline 32 & Stone, day, and glass products & 0.0988 & 0.0422 & $0.7023^{* *}$ & 0.4764 \\
\hline 33 & Primary metal industries & $0.1876 * *$ & $0.1206 * *$ & $0.9746 * *$ & 0.6843 \\
\hline 34 & Fabricated metal products & $0.3413^{* *}$ & $0.2392 * *$ & $0.9810^{* *}$ & 0.7500 \\
\hline 35 & Industrial mach. and equip. & $0.2300 * *$ & $0.1266 * *$ & $0.8324^{* *}$ & 0.7099 \\
\hline 36 & Electronic and other elect. equip. & 0.1416 & 0.0910 & $0.9452 * *$ & 0.6959 \\
\hline 37 & Transportation equipment & $0.2492 * *$ & $0.1059 * *$ & $0.9215^{* *}$ & 0.5497 \\
\hline 38 & Instruments and related prods. & $0.2593^{*}$ & $0.1337^{*}$ & $0.9460 * *$ & 0.6859 \\
\hline 39 & Misc. manuf. industries & 0.0550 & 0.0059 & $0.8418^{* *}$ & 0.6887 \\
\hline 50 & Wholesale durable goods & -0.0493 & -0.0331 & $0.9615^{* *}$ & 0.7530 \\
\hline 51 & Wholesale nondurable goods & $1.0537^{* *}$ & $0.3746 * *$ & $0.9583 * *$ & 0.3613 \\
\hline 52 & $\begin{array}{l}\text { Retail building materials } \\
\text { and garden supplies }\end{array}$ & 0.3295 & 0.2190 & $1.0040 * *$ & 0.6516 \\
\hline 53 & Retail genl. merchandise stores & $0.5041^{* *}$ & $0.2890 * *$ & $0.7025^{* *}$ & 0.7281 \\
\hline 54 & Retail food stores & 0.1275 & 0.0344 & $0.9647^{* *}$ & 0.2902 \\
\hline 55 & Auto dlrs. and service stations & $0.4072^{*}$ & $0.3262 * *$ & $1.0081 * *$ & 0.6893 \\
\hline 56 & Retail apparel and acces. stores & $0.4832^{* *}$ & $0.2673 * *$ & $0.7686 * *$ & 0.7689 \\
\hline 57 & $\begin{array}{l}\text { Retail furniture and } \\
\text { home furnishings stores }\end{array}$ & $0.6035 * *$ & $0.5153^{* *}$ & $0.9664^{* *}$ & 0.8233 \\
\hline 58 & Retail eating and drinking places & $0.3680 * *$ & $0.0453^{* *}$ & $0.9861 * *$ & 0.1700 \\
\hline 59 & Misc, retail establishments & $0.2941^{* *}$ & $0.2459 * *$ & $0.8740 * *$ & 0.8142 \\
\hline
\end{tabular}

*Significant at 95 percent confidence level; **Significant at the 99 percent confidence level. 
which leads to a target inventory level. As West (1986 and 1990) observes, inventory models that include a target level of inventory tend to perform better empirically than pure production-smoothing models. ${ }^{5}$

\section{EVIDENCE THAT SOME COMPANIES SMOOTH SEASONALLY}

Although wholesale SIC codes 50 and 51 fail both the production-smoothing and the buffer-stock tests, there are some companies in the sample that appear to smooth on a seasonal basis. That is, when sales exhibit strong seasonal patterns, inventories are increased during slower quarters and drawn down during peak sales periods. Figure 1 shows sales, inventory, and inventory-to-sales ratio for one such company. The seasonality is obvious in the data. What's more, the negative correlation between inventory movements and sales over the seasonal cycle is also obvious. The accentuated seasonal movement in the inventory-to-sales ratio confirms the buffer stock role that inventory plays, rising during periods of low sales and increasing inventories, and falling during periods of high sales and falling inventories.

The company in Figure 1 is from the SIC code 5070, which is the wholesale hardware, plumbing, and heating equipment industry. The seasonality of this industry is probably linked to the seasonality of construction. Inventory movement suggests that the firm smooths purchases seasonally, and indeed the computed ratio of the variance of purchases/production to the variance of sales for the period is 0.94 for this firm.

Figure 2 shows another wholesale company, this time in the miscellaneous whol esale trade durable goods industry, which also appears to be smoothing seasonally. The ratio of the variance of purchases/production to sales over the sample period is 1.097, however, a result that contradicts the hypothesis of smoothing. But as the chart shows, mean sales increased significantly after the first
Figure 1

\section{Company A in SIC Code 5070}

Wholesale Hardware, Plumbing and Heating Equipment

\$ Millions (Quarterly)

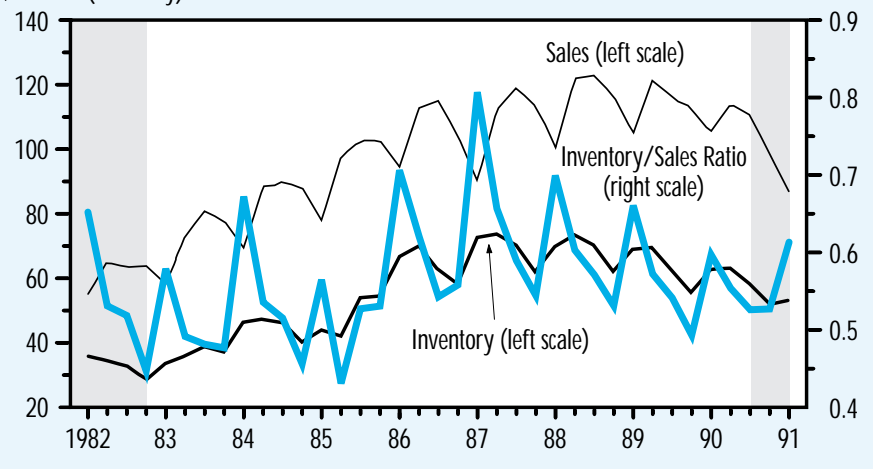

\section{Figure 2}

Company B in SIC Code 5090

Miscellaneous Wholesale Trade Durable Goods

\$ Millions (Quarterly)

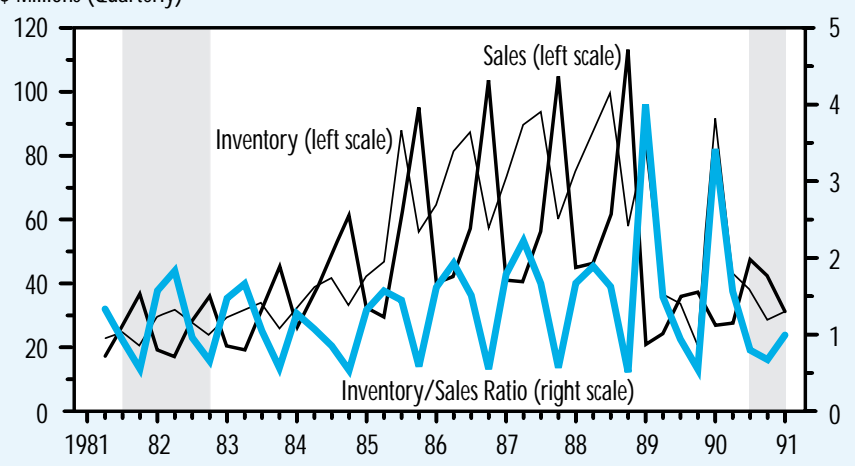

four years of the sample period. Splitting the sample into four-year pieces yields variance ratios of 0.641 for the period from the second quarter of 1981 to the second quarter of 1985 and 0.774 for the period from the third quarter of 1985 to the third quarter of 1989, confirming smoothing in both subsample periods.

Two more examples in SIC code 51, wholesale nondurables, also show evidence of seasonal smoothing. Both firms are in SIC Code 5140, groceries and related products. Figure 3 shows one company with
${ }^{5}$ Michael C. Lovell mentioned to me in a conversation once that despite the existence of sophisticated inventory methods, an informal sunvey of firms revealed a preference for target levels of inventory as a function of sales. This would also help to explain the empirical findings. 


\section{Figure 3}

\section{Company C in SIC Code 5140}

Wholesale Nondurable Goods-Groceries and Related Products \$ Millions (Quarterly)

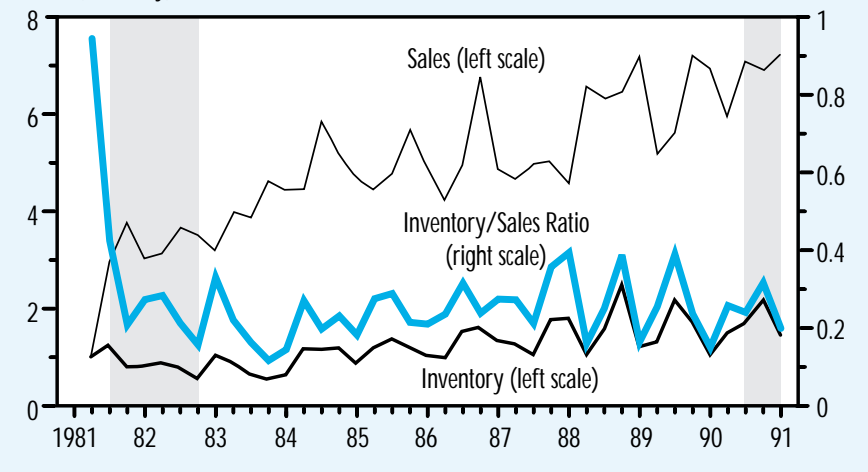

\section{Figure 4}

\section{Company D in SIC Code 5140}

Wholesale Nondurable Goods-Groceries and Related Products \$ Millions (Quarterly)

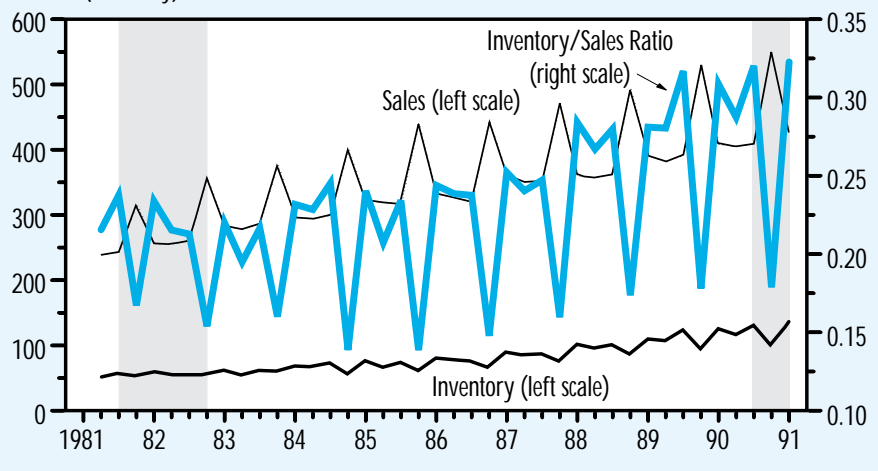

mean sales of approximately $\$ 5$ million per quarter and inventory-to-sales ratio of 0.27 . The variance ratio of this company is 0.95 , confirming what appears to be seasonal smoothing. Figure 4 shows another company with mean sales of $\$ 356$ million and with a lower inventory-to-sales ratio of 0.23 . This company has a variance ratio of 0.91 , which confirms the assumption that there was smoothing over the sample period. The important characteristic that allows us to confirm smoothing appears to be the relatively flat sales over the sample period. The seasonal rise and fall of the inventory-tosales ratio also gives some indication of the degree of smoothing.

\section{CONCLUSIONS/ SUMMARY}

The common assumption is that firms use inventories to smooth production. Like previous research based on aggregate data, however, my research at the level of individual companies fails to confirm this hypothesis, although select firms showed evidence of seasonal smoothing. But the results do confirm the stylized empirical regularity that production varies more than sales, both at the firm level and in the aggregate. Using the variance ratio test for production smoothing, I found that both the individual firm average and the SIC code aggregate exceeded 1.0 in most cases. Aggregation over the 2-digit SIC codes did not appear to be a major factor.

One possible explanation of the failure to confirm smoothing is that increased demand prompts firms to raise their inventory targets levels; thus "planned" inventory increases are positively correlated with sales. Unplanned inventory changes, which would reflect the buffer stock motivation, are negatively correlated with sales but insufficient to make the variance of production less than that of sales. In the buffer stock test of the correlation between changes in sales and changes in inventory, most firms and 2-digit industrial classifications showed negative correlations. This finding is consistent with the idea that inventories act as a buffer stock to unexpected changes in sales. The negative correlation between changes in sales and changes in inventory may be a better test of whether buffer stock movement is prompted by random demand in the presence of partial adjustment and serially correlated demand.

Ordinary least squares estimates of the coefficients of the simple partial adjustment model yielded statistically significant and appropriately signed coefficients in 21 of the 37 industries. This result al so seems to suggest that many industries may be making partial adjustments in their inventories. 


\section{REFEREN CES}

Allen, Donald S. "Changes in Inventory Management and the Business Cyde," this Review (July/ August 1995), pp. 17-26.

Blinder, Alan S. "Can the Production Smoothing Model of Inventory Behavior be Saved?" Quarterly Joumal of Economics (August 1986), pp. $431-53$.

Fair, Ray C. "The Production-Smoothing Model is Alive and Well," Journal of Monetary Economics (November 1989), pp. 353-70.

Ghali, Moheb A. "Seasonality, Aggregation and the Testing of the Production Smoothing Hypothesis," The American Economic Review (June 1987), pp. 464-69.

Krane, Spencer D., and Steven N. Braun. "Production Smoothing Evidence from Physical-Product Data," Journal of Political Economy (June 1991), pp. 558-81.

Lovell, Michael C. "Researching Inventories: Why Haven't We Learned More?" International Joumal of Production Economics (June 1994), pp. 3341.

_..... "Simulating the Inventory Cycle," Journal of Economic Behavior and Organization (June 1993), pp. 147-79.

Miron, Jeffrey A., and Stephen P. Zeldes. "Seasonality, Cost Shocks, and the Production Smoothing Model of Inventories," Econometrica (July 1988), pp. 877-908.

West, Kenneth D. "A Variance Bounds Test of the Linear Quadratic Inventory Model," Journal of Political Economy (April 1986), pp. 374.401.

. . . "The Sources of Fluctuations in Aggregate Inventories and GNP," Quarterly Joumal of Economics (November 1990), pp. 939-71. 


\section{Appendix-Table A}

\section{Descriptive Statistics of Data}

\begin{tabular}{|c|c|c|c|c|c|c|}
\hline \multirow[t]{2}{*}{ SIC Code } & \multirow[t]{2}{*}{ Industry } & \multirow{2}{*}{ \# of Cos. } & \multicolumn{2}{|c|}{$\begin{array}{c}\text { Sales } \\
\text { \$ Millions }\end{array}$} & \multicolumn{2}{|c|}{$\begin{array}{l}\text { Inventory } \\
\text { \$ Millions }\end{array}$} \\
\hline & & & Mean & S.D. & Mean & S.D. \\
\hline 10 & Metal mining & 36 & 587.6 & 1591.3 & 451.9 & 1350.5 \\
\hline 12 & Coal mining & 4 & 2144.2 & 2421.7 & 660.9 & 592.0 \\
\hline 13 & Oil and gas extraction & 102 & 2867.0 & 18274.4 & 787.2 & 4316.6 \\
\hline 14 & Nonmetallic minerals, except fuels & 9 & 2458.0 & 3456.1 & 1022.0 & 1434.5 \\
\hline 15 & General building contractors & 36 & 3125.4 & 4966.6 & 4271.5 & 5167.2 \\
\hline 16 & Heavy construction, except bldg. & 13 & 10466.8 & 19364.0 & 3333.2 & 5994.9 \\
\hline 17 & Special trade contractors & 17 & 1146.4 & 2237.8 & 264.5 & 564.4 \\
\hline 20 & Food and kindred products & 101 & 14264.7 & 25629.9 & 6360.4 & 11617.4 \\
\hline 21 & Tobacco products & 7 & 33943.4 & 44849.6 & 32265.3 & 40746.4 \\
\hline 22 & Textile mill products & 40 & 3910.1 & 6364.7 & 2812.0 & 4871.5 \\
\hline 23 & Apparel and other textile products & 45 & 1975.8 & 3425.5 & 1717.8 & 2871.4 \\
\hline 24 & Lumber and wood products & 27 & 1330.5 & 2770.6 & 631.2 & 1301.8 \\
\hline 25 & Furniture and fixtures & 30 & 2934.4 & 5206.3 & 2108.8 & 5037.7 \\
\hline 26 & Paper and allied products & 47 & 13904.5 & 21318.2 & 6560.1 & 12072.0 \\
\hline 27 & Printing and publishing & 66 & 4499.2 & 6861.4 & 1249.4 & 2295.8 \\
\hline 28 & Chemicals and allied products & 188 & 10942.3 & 31451.3 & 6211.5 & 17002.1 \\
\hline 29 & Petroleum and coal products & 37 & 106119.8 & 185077.1 & 29652.0 & 52072.2 \\
\hline 30 & Rubber and misc. plastics products & 66 & 3509.1 & 12557.8 & 2051.9 & 7416.1 \\
\hline 31 & Leather and leather products & 18 & 1801.8 & 3589.9 & 1553.7 & 2906.8 \\
\hline 32 & Stone, clay, and glass products & 25 & 5792.5 & 9817.0 & 2731.7 & 4249.2 \\
\hline 33 & Primary metal industries & 81 & 8416.4 & 15782.5 & 5639.5 & 11050.9 \\
\hline 34 & Fabricated metal products & 83 & 2924.2 & 5062.6 & 2177.9 & 3795.6 \\
\hline 35 & Industrial mach. and equip. & 297 & 5912.9 & 31654.8 & 4119.4 & 18972.6 \\
\hline 36 & Electronic and other elect. equip. & 267 & 4213.9 & 25335.1 & 2894.9 & 15170.4 \\
\hline 37 & Transportation equipment & 102 & 23862.0 & 74175.8 & 12722.4 & 33568.2 \\
\hline 38 & Instruments and related prods. & 232 & 2521.1 & 12757.5 & 1698.0 & 8011.8 \\
\hline 39 & Misc. manuf. industries & 51 & 1068.6 & 2167.5 & 692.0 & 1252.1 \\
\hline 50 & Wholesale durable goods & 130 & 1532.2 & 2830.2 & 1151.7 & 2350.5 \\
\hline 51 & Wholesale nondurable goods & 70 & 7946.8 & 16810.5 & 2863.2 & 5395.2 \\
\hline 52 & $\begin{array}{l}\text { Retail building materials } \\
\text { and garden supplies }\end{array}$ & 14 & 4618.1 & 5878.4 & 3018.0 & 3665.9 \\
\hline 53 & Retail genl. merchandise stores & 47 & 34161.6 & 75829.0 & 24360.9 & 49820.7 \\
\hline 54 & Retail food stores & 40 & 26240.1 & 44964.2 & 7653.5 & 13774.9 \\
\hline 55 & Auto dlrs. and service stations & 5 & 1868.0 & 2532.0 & 1321.9 & 1776.3 \\
\hline 56 & Retail apparel and acces. stores & 31 & 6739.4 & 12129.2 & 4979.1 & 9492.1 \\
\hline 57 & $\begin{array}{l}\text { Retail furniture and } \\
\text { home furnishings stores }\end{array}$ & 24 & 1692.1 & 2508.6 & 1386.0 & 1943.7 \\
\hline 58 & Retail eating and drinking places & 56 & 2537.2 & 7290.2 & 400.9 & 1567.2 \\
\hline 59 & Misc, retail establishments & 53 & 3362.9 & 7027.0 & 2737.2 & 5918.0 \\
\hline
\end{tabular}

